\title{
Post-grazing Scots pine colonization of mid-elevation heathlands: population structure, impact on vegetation composition and diversity
}

\author{
Thomas CURT $^{\mathrm{a} *}$, Bernard PRÉvosto ${ }^{\mathrm{a}}$, Mario KLESCZEWSKI ${ }^{\mathrm{b}}$, Jacques LEPART $^{\mathrm{b}}$ \\ ${ }^{a}$ Cemagref, Applied Ecology of Woodlands, 24 av. des Landais, BP 50075, 63172 Aubière Cedex, France \\ b CNRS, Centre d'Ecologie Fonctionnelle et Évolutive, 1919 route de Mende, 34293 Montpellier Cedex 5, France
}

(Received 24 June 2002; accepted 10 February 2003)

\begin{abstract}
Scots pine (Pinus sylvestris L.) pioneer woodlands have established spontaneously on former grasslands and heathlands on MontLozère (Cévennes National Park, France) since their abandonment in the 1950's. Subsequently, late-successional beech (Fagus sylvatica L.) has progressively invaded the ageing pine stands. We studied 44 plots according to a gradient of forest colonization and maturation, from heathlands to mature beech stands. The objective was to assess the impact of forest colonization on the vegetation composition and richness of legally-protected grasslands and heathlands. Dendrometric characteristics and demography were assessed on each $20 \times 20 \mathrm{~m}$ plot. An extensive ground vegetation analysis was carried out, focusing on plant functional traits that may be sensitive to canopy closure. Results indicated the persistence of most heathland species under pure and young Scots pine stands, but quite high species turnover. Xerothermic and strictly shadeintolerant species rapidly disappeared, whereas thermophilic forest species were apparent. In submature and mature pine stands, the establishment of a beech understorey entailed considerable species turnover, and prevent pine regeneration. In pure beech stands, ruderal and stress-tolerators were replaced by shade-tolerant and competitive species. Ellenberg's scores for light, nutrients and water confirmed the changes in vegetation composition and plant life traits, whereas the Shannon diversity index remained quite constant among pure and mixed pine stands.
\end{abstract}

natural afforestation / Scots pine (Pinus sylvestris L.) / European beech (Fagus sylvatica L.) / Ellenberg indicator values / plant life traits

Résumé - Colonisation des landes de moyenne montagne par le pin sylvestre après abandon du pâturage : structure des peuplements, impact sur la composition et la diversité de la végétation. Des peuplements pionniers de pin sylvestre (Pinus sylvestris L.) se sont installés spontanément sur les landes et pelouses du Mont-Lozère (Parc National des Cévennes, France) après l'abandon de pâturage ovin vers 1950. Les espèces de fin de succession comme le hêtre (Fagus sylvatica L.) se sont progressivement infiltrées dans les peuplements de pin vieillissants. Nous avons étudié 44 placettes suivant un gradient de colonisation et de maturation forestière depuis les landes et pelouses jusqu'à la hêtraie mature, afin d'étudier l'impact de la forêt sur la flore des landes et pelouses. Sur chaque placette de $20 \times 20 \mathrm{~m}$, nous avons effectué un inventaire démographique et dendrométrique complet, et des relevés exhaustifs de la végétation. Les traits de vie des espèces susceptibles d'indiquer les effets de la colonisation forestière ont ensuite été relevés. Les résultats indiquent une persistance de nombreuses espèces de milieux ouverts sous les boisements naturels de pin, malgré des changements importants de composition. Les espèces xérothermiques et strictement héliophiles disparaissent rapidement, alors qu'apparaissent des espèces des forêts thermophiles. Dans les boisements de pin plus matures, l'installation du hêtre en sous-bois entraîne un important renouvellement des espèces et empêche la régénération naturelle du pin. Dans les hêtraies pures, les espèces rudérales et stress-tolérantes sont remplacées par des espèces d'ombre et des espèces compétitives longévives. Les coefficients d'Ellenberg pour la lumière, l'eau et les nutriments sont de bons indicateurs des changements de végétation, alors que l'indice de diversité de Shannon reste assez constant dans tous les boisements naturels de pin.

boisement naturel / pin sylvestre (Pinus sylvestris L.) / hêtre (Fagus sylvatica L.) / coefficients d'Ellenberg / traits de vie des plantes

\section{INTRODUCTION}

Large areas of heathland and grassland throughout the world have undergone shrub encroachment or invasion by pioneer woody species in the past few decades, following the reduction or abandonment of traditional grazing practices [4, 44]. In particular, Pinus sylvestris has exhibited high invasive ability in southeastern France, owing to high reproductive rates [47], efficient short- and long-distance dispersal [14], and high survival rates of propagules [15]. Moreover, it has benefited from the existence of 'regeneration windows' [37, 44] following the abandonment of former agricultural and grazing practices.

Such pine colonization or invasion of grasslands and heathlands possibly results in decreased plant diversity due to the

*Corresponding author: thomas.curt@ cemagref.fr 
extinction of resident species [26, 46], modification of the light regime [12], soil acidification and change of humus form and patterns of nutrient cycling [43].

In the Mont-Lozère area, the preservation of diversity of species-rich heathlands and grasslands is now a priority for the land managers of the Cévennes National Park. Nardus-dominated grasslands and heathlands on acid, nutrient-depleted and sandy soils occupy the central upper part of Mont-Lozère (150 $\mathrm{km}^{2}$ ). They are protected according to the "Natura 2000" European regulation owing to their spatial regression and regional rarity, and to the presence of relict alpine species [8]. This mosaic results from traditional extensive grazing, shrub-clearing and burning practices, which have been almost completely abandoned since the 1950's [32]. Pioneer Pinus sylvestris woodlands expanded spontaneously after land abandonment, from pre-existing seed sources (i.e. isolated pine stands) located at the vicinity of grasslands. Subsequently, late-successional broadleaf species such as beech (Fagus sylvatica L.) progressively infiltrated the ageing pine stands. Similar patterns of forest succession have been described in France [48, 52] and other European countries [1, 17, 21, 57]. At present, a potential conflict exists between nature conservation objectives (i.e. maintaining the specific diversity and openness of heathlands) and spontaneous forest dynamics (i.e. colonization of open areas).

The aim of this study was to assess to what extent vegetation diversity and richness may change after tree establishment and canopy closure. We selected 44 plots in a small study area, according to a stand maturation gradient from heathlands to mature beech stands. Our approach was based on two successive steps: (i) an exhaustive demographic and dendrometric analysis of forest stands in order to characterize the colonization process and determine successional stages; (ii) the assessment of biological and functional traits of individuals (= species) and species groups (= functional groups) [34] such as their dispersal mode and adaptive strategies [22, 23]. Analysis of the functional traits of vegetation species was proven efficient for describing changes in plant communities in response to disturbance [34]. This approach was completed by the use of Ellenberg scores [18] that allow relating vegetation composition with light-, water- and nutrient regimes [17, 49].

\section{MATERIALS AND METHODS}

\subsection{Study sites}

The study area $(2.5 \times 1 \mathrm{~km})$ is located on Mont-Lozère in the southeastern French Massif Central $\left(44^{\circ} 5^{\prime} \mathrm{N}, 3^{\circ} 8^{\prime} \mathrm{E}\right)$. It is composed of north-facing slopes $(1200-1300 \mathrm{~m})$ surrounding a gently sloping plateau (1300-1450 m). Soils are strongly nutrient-depleted acidic brown soils and gently podzolized soils on a granitic basement This area was chosen as representative of the forest colonization process on formerly grazed heathlands. The upper plateau is a mosaic of heathlands dominated by Festuca rubra, Calluna vulgaris, Vaccinium myrtillus, Deschampsia flexuosa and Genista purgans [8], and Nardus-dominated grasslands (Nardetea strictae Rivas Goday \& Borja Carbonell 61) (see Appendix). These communities (indicated below as 'heathlands') partly result from grazing practices, and naturally evolve towards acidic beech forests $[8,32]$. They exhibit low grazing values, but are locally protected because of their spatial regression, and the presence of certain relict alpine species such as Leontodon pyrenaici subsp. helveticus and Potentilla aurea. The heathlands are surrounded by pine woodlands and mature beech stands. Mixed pine-beech stands have established spontaneously with the contact between the two species.

Heathlands were grazed by sheep and then cows till the 1950's, after which grazing decreased considerably along with the decline of the traditional agropastoral system, thus favoring spontaneous forest colonization. Extensive and sporadic cattle grazing existed in the upper part of the plateau throughout the past decade. A diachronic analysis of aerial photographs (1947 to 1999 at an approximate 8-years step) allowed formulating a pattern of forest colonization (Fig. 1). During an initial colonization step (1947-1963) after grazing ceased, pine spread from small and isolated stands located in the vicinity of a hamlet that traditionally provided wood and shelter for cattle. This initial spread was very rapid since the pioneer pine front extended to most parts of the plateau. During a second step, the woodlands tended to get denser after which gaps developed in the ageing pine stands (1980's), thus allowing the progressive establishment of beech (Fagus sylvatica L.) under the pine canopy. Beech was probably disseminated from neighboring mature beech stands by jays and small rodents [38].

\subsection{Sample plan}

The sample plan aimed at selecting plots according to the widest colonization gradient from open heathlands to mature beech stands. The analysis of aerial photographs and a dendrometric survey resulted in six contrasting physiognomic and dendrometric categories corresponding to the main successional stages (Tab. I): (1) grasslands and heathlands without tree colonization; (2) heathlands in the process of being colonized, characterized by the patchy structure of the initial resident vegetation and scattered pines; (3) dense and young Scots pine stands, characterized by almost complete canopy closure; (4) submature Scots pine stands with recent beech installation, i.e. young $(<15$ yrs.) and scattered beech saplings; (5) mature Scots pine stands with old beech individuals (15-40 yrs.); (6) mature and pure beech forest. Forest stands were unmanaged, i.e. they experienced no silvicultural practices such as thinning or clearing.

In all 44 plots were studied with a minimum of 6 replicates per category (Tab. I). Sampling was done along parallel transects with the help of a GPS device: the $20 \times 20 \mathrm{~m}$ plots were established approximately every $-200 \mathrm{~m}$ from open heathlands to beech stands. Parallel transects allowed replicating plots with similar site conditions and physiognomy.

\subsection{Field data collection}

We assessed site variables on each $20 \times 20$ m plot: elevation, slope and soil type. An exhaustive survey of vascular species was carried out in the spring and summer of 2001, using the Braun-Blanquet [7] abundance-dominance scale (see Appendix). In addition, the cover of all vegetation layers (i.e. overstorey, shrubs, herbaceous vegetation, mosses and soil litter) was estimated visually.

Stand description included an exhaustive demographic inventory of all seedlings ( $>2 \mathrm{yr}$.), saplings and adult individuals of tree species (Pinus sylvestris, Fagus sylvatica and companion species such as Betula pendula). Each living ligneous species was measured: basal circumference, diameter at stem base, total height, and crown width in two perpendicular directions. The age of young saplings was assessed by counting whorls (Scots pine) or growth units (beech), and the age of larger trees was estimated by ring-counting on cores taken at the stem base. 

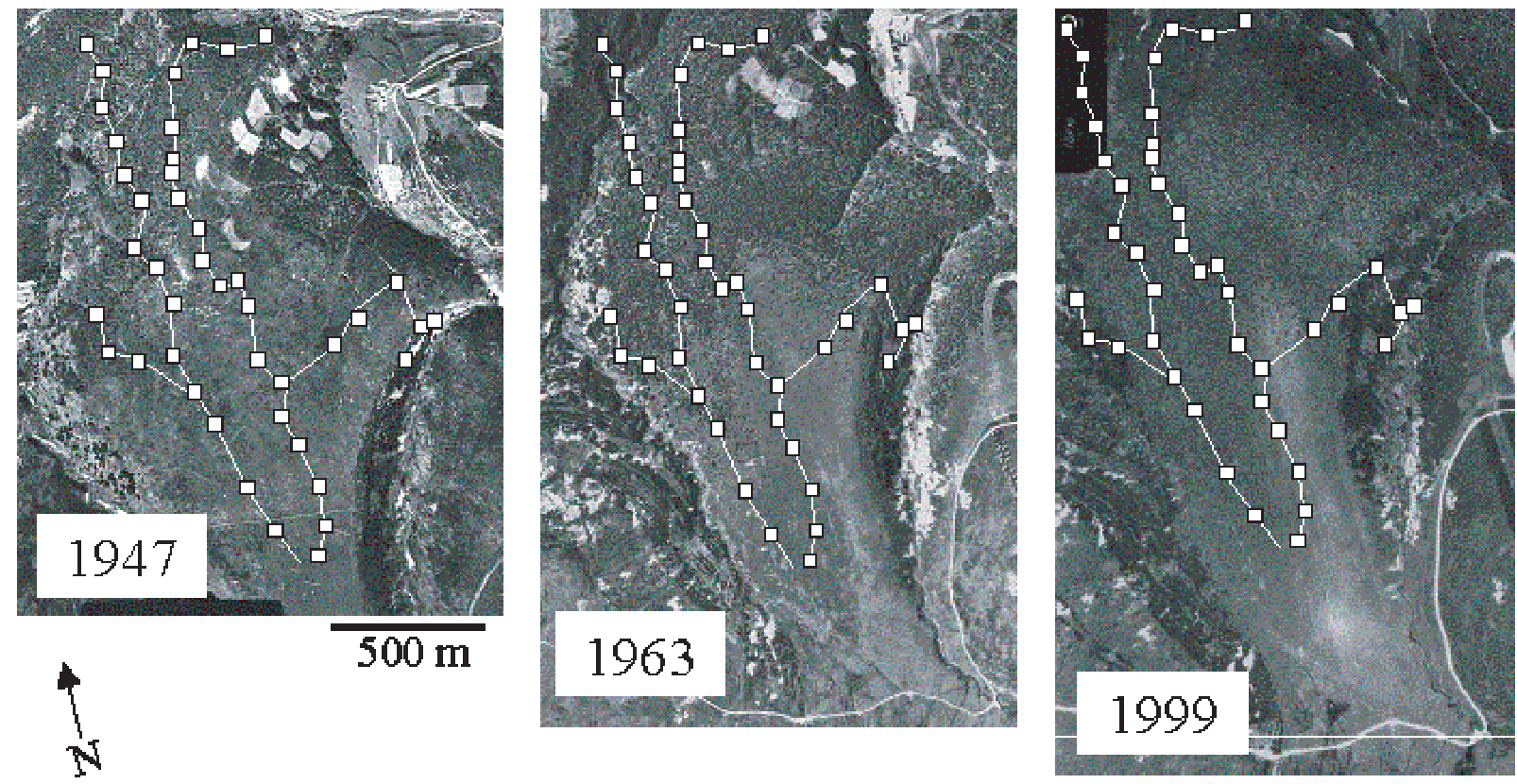

Figure 1. Aerial photographs of the study area in 1947, 1963 and 1999. White squares indicate the approximate location of the 44 sample plots.

Table I. Main stand characteristics of the six physiognomic and dendrometric categories. Values are means \pm standard errors.

\begin{tabular}{|c|c|c|c|c|c|c|}
\hline $\begin{array}{l}\text { Physiognomic and dendrometric } \\
\text { categories }\end{array}$ & $\begin{array}{l}\text { Open grasslands- } \\
\text { heathlands }\end{array}$ & $\begin{array}{l}\text { Young pine } \\
\text { clusters }\end{array}$ & $\begin{array}{l}\text { Dense and young } \\
\text { pine stands }\end{array}$ & $\begin{array}{c}\text { Submature } \\
\text { pine-beech stands }\end{array}$ & $\begin{array}{c}\text { Mature } \\
\text { pine-beech stands }\end{array}$ & $\begin{array}{l}\text { Mature beech } \\
\text { stands }\end{array}$ \\
\hline Number of plots & 7 & 9 & 7 & 6 & 8 & 7 \\
\hline Pine age (mean $\pm \mathrm{SE})$ & & $10 \pm 2$ & $10 \pm 3$ & $39 \pm 3$ & $46 \pm 5$ & \\
\hline Beech age (mean $\pm \mathrm{SE})$ & & & & $7 \pm 1$ & $13 \pm 5$ & $150^{*}$ \\
\hline Pine stand density $\left(n \cdot h a^{-1}\right) \pm S E$ & & $425 \pm 178$ & $3500 \pm 1800$ & $575 \pm 102$ & $469 \pm 213$ & \\
\hline Beech stand density $\left(n \cdot h a^{-1}\right) \pm$ SE & & & & $750 \pm 318$ & $2050 \pm 720$ & Not measured \\
\hline Pine basal area $\left(\mathrm{m}^{2} \cdot \mathrm{ha}^{-1}\right)$ & & 1.7 & 2.5 & 28.5 & 28.4 & \\
\hline Beech basal area $\left(\mathrm{m}^{2} \cdot \mathrm{ha}^{-1}\right)$ & & & & 0.8 & 3.2 & Not measured \\
\hline Cover by high ligneous (> $1 \mathrm{~m}), \%$ & $2 \pm 1$ & $2 \pm 1$ & $44 \pm 11$ & $25 \pm 10$ & $34 \pm 11$ & $94 \pm 1$ \\
\hline Cover by small ligneous $(<1 \mathrm{~m}), \%$ & 0 & $6 \pm 2$ & $5 \pm 2$ & $3 \pm 1$ & $5 \pm 3$ & $1 \pm 0.5$ \\
\hline Cover by herbaceous layer, $\%$ & $95 \pm 1$ & $71 \pm 10$ & $78 \pm 11$ & $85 \pm 9$ & $86 \pm 5$ & $3 \pm 1$ \\
\hline Cover by the holorganic humus layer & $5 \pm 4$ & $1 \pm 0.5$ & $4 \pm 4$ & $8 \pm 3$ & $43 \pm 19$ & $93 \pm 3$ \\
\hline
\end{tabular}

* The age of beech stands was estimated according to cadastral data.

\subsection{Computation of vegetation indices}

Several vegetation indices were computed (Tab. II). Firstly, we computed the Shannon-Weaver [50] index based on a numericallytransformed Braun-Blanquet scale [55]; secondly, we assessed the Sørensen similarity index using pooled species for each group; and thirdly, we calculated the original richness index, which corresponds to the number of species that are present in a specific stage, and absent from any other stage [56].

Plant functional indices and life traits that were likely to modify the abundance of species along the succession or in response to disturbance (i.e. grazing or forest colonization) were assessed (Tab. II). The database comprised the main biological and auto-ecological traits such as life form [33, 45], dispersal mode [33], biogeographic origin [18], grazing value [13], and adaptive strategy according to Grime's CSR-classification [22, 23]. Endemic species were listed according to Braun-Blanquet [8] and the personal knowledge of a member of the team. The Ellenberg indicator values [18, 33] for light, moisture, nitrogen, acidity, nutrient availability, temperature and continentality were also calculated on the basis of the absence or the presence of species. The Ellenberg classification proved to be adapted to most European ecosystems [49] and in particular to French ecosystems [28]. Data on functional and life traits were available for about $84 \%$ of species (excluding mosses) whereas the Grime's CSR strategy was only available for about $65 \%$ of species. Since the rate of available data was quite similar amongst successional stages, species whose data were unknown were omitted from analysis. 
Table II. Computed vegetation indices and vegetation life traits: reference and assessment method.

\begin{tabular}{|c|c|c|}
\hline Computed vegetation indices & Reference & Assessment method \\
\hline $\begin{array}{l}\text { Transformation of Braun-Blanquet abundance- } \\
\text { dominance scale [7] in numeric values }\end{array}$ & {$[7,55]$} & $\begin{array}{l}\text { Abundance-dominance coefficients }(\mathrm{AD}) \text { are transformed in numeric values correspon- } \\
\text { ding to the mid-class: AD+: } 0.1 \% \text {; AD1: } 5 \% \text {; AD2: } 17.5 \% \text {; AD3: } 37.5 \% \text {; AD4: } 62.5 \% \text {; } \\
\text { AD5: } 87.5 \%\end{array}$ \\
\hline \multirow[t]{2}{*}{ Shannon-Weaver diversity index $(\mathrm{H})$} & \multirow[t]{2}{*}[50]{} & $\begin{array}{l}H=-\sum_{i=1}^{S} p i \log _{2} p i \text { with: } S=\text { number of species; a } i=\text { recovery for the } i \text { species; } \\
n i=\underline{a i}\end{array}$ \\
\hline & & $\sum_{i=1}^{S} a i$ \\
\hline \multirow[t]{2}{*}{ Sørensen similarity index } & \multirow[t]{2}{*}{ [29] } & $S I_{A B}=\frac{2 c}{(a+b+2 c)}$ \\
\hline & & $\begin{array}{l}\text { with: } \mathrm{a}=\text { number of species specific to } \mathrm{A} ; \mathrm{b}=\text { number of species specific to } \mathrm{B} ; \mathrm{c}=\text { num- } \\
\text { ber of species common to } \mathrm{A} \text { and } \mathrm{B} . \mathrm{A} \text { and } \mathrm{B} \text { are two different stages }\end{array}$ \\
\hline Original richness index & {$[56]$} & $\begin{array}{l}\text { The original richness index is the number of species that are present in a specific stage, } \\
\text { and absent from any other stage }\end{array}$ \\
\hline \multicolumn{3}{|l|}{ Plant functional and life traits } \\
\hline Life form & {$[22,33,45]$} & $\begin{array}{l}\text { Phanerophytes, nanophanerophytes, chamaephytes, hemi-cryptophytes, geophytes, } \\
\text { therophytes }\end{array}$ \\
\hline Dispersal mode & [33] & Autochory, barochory, anemochory, hydrochory, zoochory, anthropochory \\
\hline Biogeographic origin & {$[18]$} & $\begin{array}{l}\text { Atlantic, cosmopolitan, Mid-European, circumboreal, Mediterranean, endemic, moun- } \\
\text { tainous }\end{array}$ \\
\hline Grazing value & {$[13]$} & $\begin{array}{l}\text { Index taking into account the palatability and consumption of each species, and its abun- } \\
\text { dance. Thorny, scented and/or toxic species (= unpalatable) were set apart and noted }\end{array}$ \\
\hline CSR-adaptive strategy & {$[22]$} & $\begin{array}{l}\text { Competitive (C), stress-tolerant (S), ruderals (R), and intermediate strategies (C-S, S-C, } \\
\text { S-R and C-S-R) }\end{array}$ \\
\hline Phytosociological association & {$[33]$} & $\begin{array}{l}\text { Nardetalia- Nardion, Violion caninae, Molinio-Arrhenatheretea, Querceti-robori + Fagetea, } \\
\text { indifferent, anthropo-zoogeneous }\end{array}$ \\
\hline
\end{tabular}

\subsection{Statistical analysis}

Comparison of species richness and diversity, and functional and life traits amongst successional stages was carried out using a one-way Analysis of variance procedure (ANOVA) on values for each survey. Pairwise mean comparisons were performed by using Fisher's LeastSquare-Difference (LSD) test with a 95\% confidence interval. Mean values and standard errors were computed for each stage. The species' turnover according to successional stages was performed by the comparison of synoptic tables grouping all the species present at a specific stage with a synoptic table grouping the species present in initial heathlands without pine colonization (= reference).

\section{RESULTS}

\subsection{Forest stand dynamics and demography}

Demographic data (Fig. 2) can help to reconstruct past pine colonization and its progressive replacement by beech. Young and dense pine stands correspond to the first step of the colonization process, such as clusters located close to the present colonization front. They exhibit a low stand density (425 trees per ha) and a reverse-J shaped distribution of age classes (Fig. 2A). Scattered older pines (30-45 yrs.) that probably correspond to maternal trees are accompanied by a higher number of young pine saplings. The second step of colonization corresponds to dense pure pine stands of maximal density (3500 trees per ha) in relation to the increase of reproductive trees (Fig. 2B). The third step corresponds to submature pine stands of decreasing density in relation to intraspecific compe- tition, and to the subsequent establishment of beech in the understory: beech has infiltrated over the last 25 yrs. with a recent peak (5-10 yrs.). In parallel, pine seedlings and young saplings (<20 yrs.) are almost completely absent (Fig. 2C), whereas they were present in younger pure pine stands. Regarding the last step, density remains low but the stands are ageing. Pine regeneration is still almost absent, whereas beech seedlings and saplings establish continuously in the understory (Fig. 2D).

Since some isolated pines existed in the heathlands before grazing practices ceased, we estimated the approximate age of abandonment as the age of the most abundant pine age class in mature stands. Taking into account this method, the colonization process would have begun around 1950 at the period of the main abandonment. The establishment of beech under the pine canopy began between 1965 and 1980, with a recent peak 5 to 10 yrs. ago.

\subsection{Floristic composition vs. stand development}

The initial heathlands were mainly composed of species belonging to Nardetalia-Nardion and Violion caninae associations (Tab. III), which decreased considerably with forest colonization. At the same time, indifferent species and species belonging to forest associations (Querceti-robori, Fagetea) and Molinio-Arrhenatheretea clearly increased. Mid-European species are predominant throughout stand maturation. Mountainous, Endemic and Mediterranean (especially high 


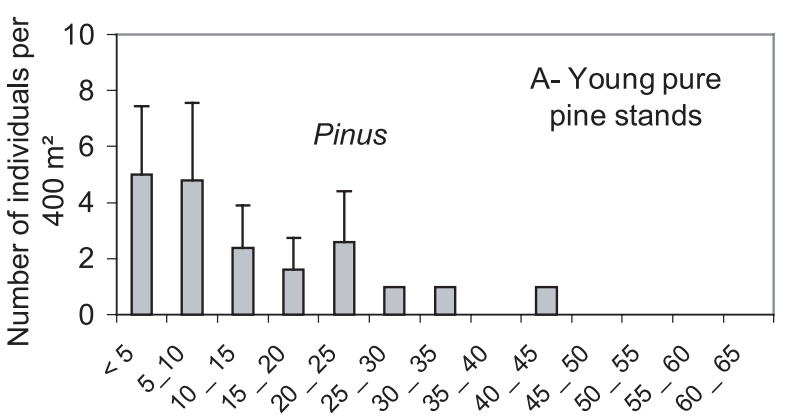

Age (yr.)

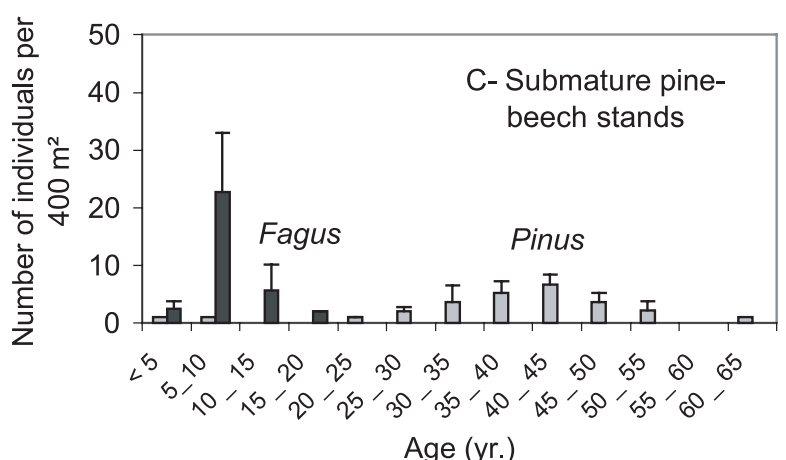

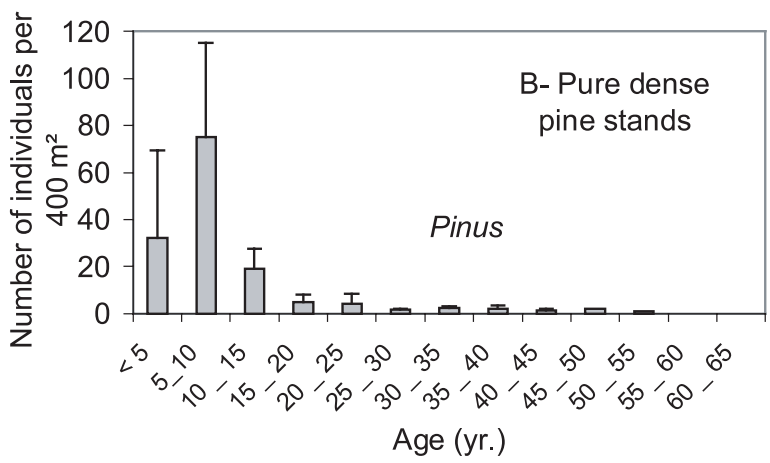

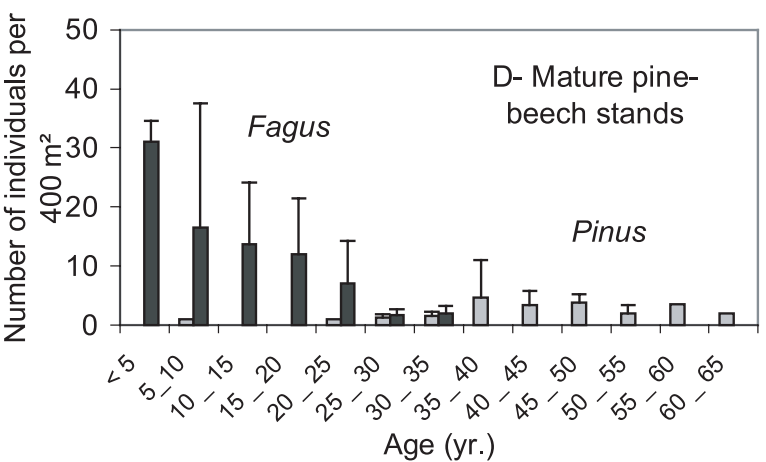

Figure 2. Demographic analysis of Pinus sylvestris (grey bars) and Fagus sylvatica (black bars) saplings and adults along the forest colonization gradient. The number of individuals is assessed on a $20 \times 20 \mathrm{~m}$ plot. The bars represent the average value for each stage, and the vertical line is the standard error. The complete characteristics of the different stages are given in Table I.

elevation-Mediterranean [8]) species such as Nardus stricta were relatively frequent in heathlands. They decreased quite regularly with tree colonization and stand maturation, whereas Cosmopolitan species increased. The other species exhibited no clear pattern of variation.

The Sørensen index (Tab. IV) indicates high similarity between the vegetation of open heathlands and that of early colonization stages (i.e. pure pine stands). Conversely, only about one-third of species from the initial heathlands persists in mixed stands. The vegetation of mature mixed stands is very similar to that of pure beech stands, and highly differentiated from that of heathlands. Beech stands exhibit specific and impoverished ground vegetation. The balance between species that have appeared and disappeared changed along the colonization gradient (Fig. 3): gain and loss are balanced at earlier stages of forest colonization, while gain was higher at intermediate stages, and loss dominates in pure beech stands.

Regarding the vegetation of initial heathlands, the establishment of pure pine stands corresponded to: (i) a statistically significant decrease of strictly shade-intolerant species of heathlands, such as Nardus stricta and Agrostis capillaris (see Appendix); (ii) an increase of herbaceous species of thermophilic forests such as Viola canina and Campanula rotundifolia; and (iii) the arrival of pioneer and shade-intolerant chamaephytes and shrubs, such as Sorbus aucuparia, Genista spp. and Vaccinium spp. The establishment of beech in the pine understory corresponds to the increase of shade mid-tolerant or tolerant species typical of mixed broadleaf-pine forests, such as Conopodium majus and Deschampsiaflexuosa. Species typ- ical of beech forests appear within the mature mixed stands, and logically dominate in pure beech stands (e.g. Prenanthes purpurea, Mä̈anthemum bifolium, Viola riviniana).

\subsection{Floristic richness and diversity vs. stand evolution}

A total of 192 species were recorded in the 44 plots. Vascular species (i.e. 159 herbaceous and 20 mosses) represented about $4.5 \%$ of the French flora [11]. The total number of species (including mosses, ligneous and herbaceous species) was maximal at intermediate stages but differences between stages were not statistically significant (Fig. 4A). At the same time, the number of ligneous species and mosses increased irregularly with stand maturation (data not shown). Pure beech stands clearly had a lower richness than all the other stages. The Shannon-Weaver diversity index exhibited similar variation along succession (Fig. 4B). The original richness of vascular species and mosses (i.e. the number of species that are present at only one stage) was clearly minimal at the beginning of the colonization process and in pure beech stands, and maximal in mature mixed stands (Fig. 4A). It is noteworthy that 20 species occurred at all stages (even with variable abundance) except beech stands, and 12 species were present in the 44 plots.

Both the Shannon-Weaver index and total species richness correlated inversely with canopy cover (i.e. the percentage of covering by the overstorey): adjusted $R^{2}$ was $51 \%$ and $41 \%$, respectively. They were quite constant until a covering of about $75 \%$, then decreased brutally and linearly (data not shown). The cover of the herbaceous layer was inversely and 
Table III. Main species' life traits and attributes according to the physiognomic stages. (1) Open grasslands and heathlands without tree colonization; (2) Grasslands in the process of being colonized (scattered pines); (3) Dense and young Scots pine stands; (4) Submature Scots pine stands with recent beech installation; (5) Mature Scots pine stands with old beech individuals; (6) Mature and pure beech forest. Values are percentages except for the grazing value. A same italic letter in a row indicates non-statistically difference (LSD procedure, $P<0.05$ ).

\begin{tabular}{|c|c|c|c|c|c|c|}
\hline Life traits and attibutes & 1 & 2 & 3 & 4 & 5 & 6 \\
\hline \multicolumn{7}{|l|}{ Biogeographic origin } \\
\hline Atlantic & $3.0 \mathrm{~b}$ & $3.0 \mathrm{~b}$ & $2.9 b$ & $4.0 \mathrm{~b}$ & $3.6 b$ & $0.0 a$ \\
\hline Cosmopolitan & $12.1 a$ & $12.1 a$ & $17.6 b$ & $24.0 \mathrm{bc}$ & $21.8 b$ & $26.7 c$ \\
\hline Mid-European & $54.5 b$ & $57.6 b$ & $55.9 b$ & $50.0 a$ & $52.7 a$ & $53.3 a$ \\
\hline Circum-boreal & $0.0 a$ & $3.0 \mathrm{~b}$ & $0.0 a$ & $4.0 \mathrm{~b}$ & $3.6 b$ & $0.0 a$ \\
\hline Mediterranean & $18.2 b$ & $12.1 a$ & $14.7 a b$ & $14.0 a b$ & $12.7 a$ & $20.0 \mathrm{~b}$ \\
\hline Endemic & $6.1 b$ & $3.0 a b$ & $2.9 a b$ & $2.0 a b$ & $3.6 a b$ & $0.0 a$ \\
\hline Mountainous & $6.1 b$ & $9.1 c$ & $5.9 b$ & $2.0 a b$ & $1.8 a b$ & $0.0 a$ \\
\hline \multicolumn{7}{|c|}{ Phytosociological association } \\
\hline Anthropo-zoogeneous & $5.9 b$ & $11.4 c$ & $10.8 c$ & $8.3 b$ & $6.0 \mathrm{~b}$ & $0.0 a$ \\
\hline Nardetalia + Nardion & $52.9 c$ & $28.6 b$ & $24.3 b$ & $16.7 b$ & $4.0 a$ & $5.3 a$ \\
\hline Violion caninae & $11.8 c$ & $11.4 c$ & $10.8 c$ & $5.6 b$ & $6.0 \mathrm{~b}$ & $0.0 a$ \\
\hline Molinio-Arrhenatheretea & $0.0 a$ & $5.7 a$ & $8.1 b$ & $11.1 b$ & $24.0 c$ & $26.3 c$ \\
\hline Querceti-robori + Fagetea & $5.9 a$ & $5.7 a$ & $5.4 a$ & $13.9 b$ & $20.0 c$ & $21.1 c$ \\
\hline Indifferent & $23.5 a$ & $37.1 b$ & $40.5 b$ & $44.4 b$ & $40.0 \mathrm{~b}$ & $47.4 b$ \\
\hline \multicolumn{7}{|l|}{ Dispersal mode } \\
\hline Autochory & $35.5 b$ & $17.6 a$ & $21.1 a b$ & $21.4 a b$ & $21.1 a b$ & $17.9 b$ \\
\hline Barochory & $0.6 a$ & $1.5 a$ & $1.4 a$ & $1.0 a$ & $1.5 a$ & $5.1 b$ \\
\hline Anemochory & $23.1 a$ & $29.4 a$ & $29.6 a$ & $25.2 a$ & $27.1 a$ & $35.9 b$ \\
\hline Hydrochory & $8.9 c$ & $5.9 a b$ & $4.2 a b$ & $7.8 c$ & $3.8 a b$ & $2.6 a$ \\
\hline Zoochory & $30.2 a$ & $44.1 b$ & $40.8 b$ & $40.8 b$ & $40.6 b$ & $35.9 a$ \\
\hline Anthropochory & $1.8 a$ & $1.5 a$ & $2.8 a b$ & $3.9 a b$ & $6.0 \mathrm{~b}$ & $2.6 a$ \\
\hline \multicolumn{7}{|l|}{ Life form } \\
\hline Phanerophytes & $0.5 a$ & $9.5 b$ & $6.7 b$ & $10.0 \mathrm{~b}$ & $11.3 c$ & $7.1 b$ \\
\hline Nanophanerophytes & $0.0 a$ & $7.1 b$ & $2.2 a$ & $6.0 \mathrm{~b}$ & $7.5 b$ & $7.1 b$ \\
\hline Chamaephytes & $30.9 c$ & $14.3 a$ & $26.7 b$ & $24.0 \mathrm{~b}$ & $18.9 a b$ & $10.7 a$ \\
\hline Hemicryptophytes & $54.1 b$ & $50.0 a$ & $57.8 c$ & $58.0 \mathrm{c}$ & $58.5 c$ & $60.7 c$ \\
\hline Geophytes & $10.3 d$ & $11.9 d$ & $4.4 b$ & $0.0 a$ & $1.9 a$ & $7.1 c$ \\
\hline Therophytes & $4.1 b$ & $7.1 c$ & $2.2 a$ & $2.0 a$ & $1.9 a$ & $7.1 c$ \\
\hline \multicolumn{7}{|l|}{ Grime's adaptive strategy } \\
\hline $\mathrm{C}$ & $5.6 b$ & $0.0 a$ & $5.2 b$ & $4.8 b$ & $5.8 b$ & $7.5 c$ \\
\hline $\mathrm{CR}$ & $7.9 c$ & $0.5 a$ & $7.8 c$ & $3.9 b$ & $5.8 b c$ & $15.1 d$ \\
\hline CSR & $40.7 c$ & $26.5 b$ & $39.6 c$ & $44.4 c$ & $40.2 c$ & $20.8 a$ \\
\hline $\mathrm{S}$ & $25.5 a$ & $37.9 b$ & $22.6 a$ & $22.7 a$ & $23.7 a$ & $20.8 a$ \\
\hline SR & $6.5 b$ & $10.4 c$ & $7.0 \mathrm{~b}$ & $4.3 a$ & $4.0 a$ & $3.8 a$ \\
\hline $\mathrm{SC}$ & $11.1 a$ & $19.0 \mathrm{~b}$ & $13.5 a$ & $15.9 b$ & $17.9 b$ & $30.2 c$ \\
\hline $\mathrm{R}$ & $2.8 b$ & $5.7 d$ & $4.3 c$ & $3.9 c$ & $2.7 b$ & $1.9 a$ \\
\hline Grazing value & $29.3 c$ & $26.0 c$ & $30.6 c$ & $23.8 b c$ & $18.3 \mathrm{~b}$ & $5.1 a$ \\
\hline Toxic + thorny species & $8.6 b$ & $15.8 c$ & $16.7 c$ & $10.9 b$ & $10.9 b$ & $5.3 a$ \\
\hline
\end{tabular}

linearly correlated to canopy cover $\left(R^{2}=0.89\right)$. Conversely, the closure by understory species had no impact on species richness and diversity.

\subsection{Functional groups vs. forest colonization and stand maturation}

Hemicryptophytes species were predominant throughout the stages, and increased slightly through the colonization process (Tab. III). Chamaephytes are especially abundant in the first stage of colonization, then decreased. The proportion of phanerophytes logically increases with stand maturation, whereas geophytes and therophytes decrease. Most plants are animal-dispersed. They are especially abundant at intermediate stages and less abundant in open heathlands and mature stands. Two main types of zoochory are maximal in woodlands: ingestion and adhesion on animals. Autochory is also 

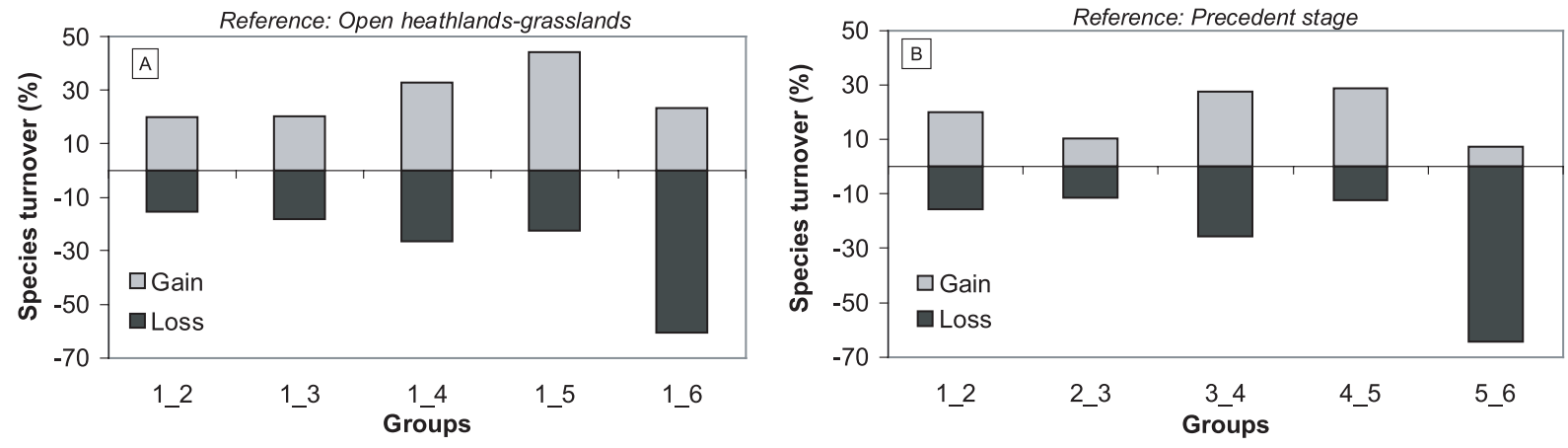

Figure 3. Specie's turnover along forest colonization and maturation. The turnover values are computed as a ratio between the species' pool of a specific stage and the pool of initial heathlands (A) or any previous stage (B). In e.g. 1_2 indicates gain and loss of species between open grasslands and heathlands without tree colonization, and grasslands in the process of being colonized (scattered pines). Physiognomic stages: (1) Open grasslands and heathlands without tree colonization; (2) Grasslands in the process of being colonized (scattered pines); (3) Dense and young Scots pine stands; (4) Submature Scots pine stands with recent beech installation; (5) Mature Scots pine stands with old beech individuals; (6) Mature and pure beech forest.
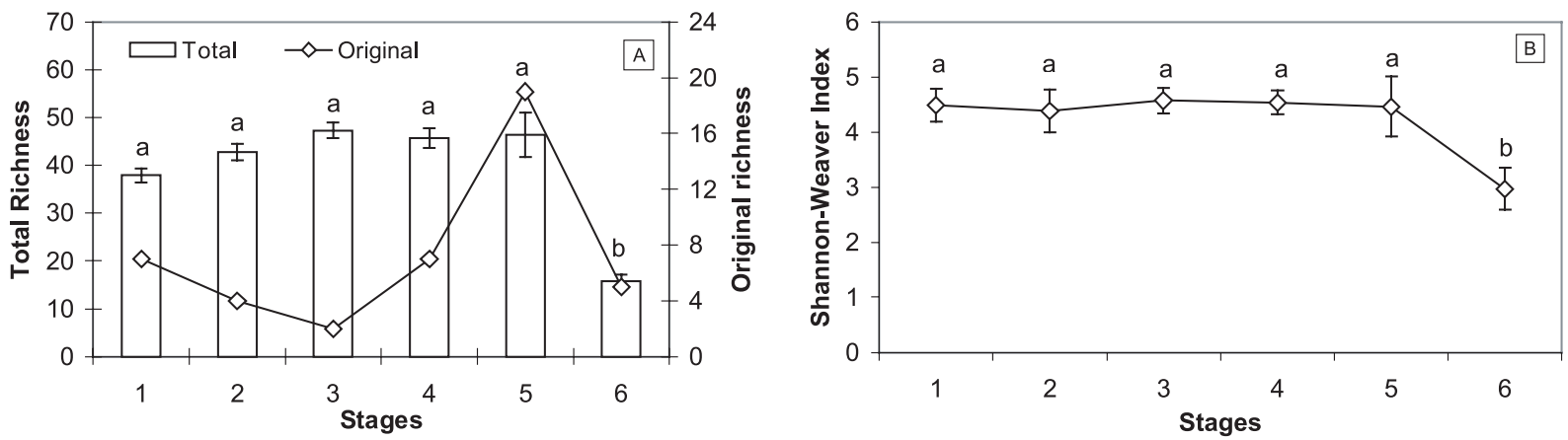

Figure 4. Total species richness and original richness (A), and Shannon-Weaver diversity index (B) according to the six main physiognomic stages. The original richness is the number of species present only at a specific stage, and absent from any other stage.

Table IV. Sørensen index of similarity between stages. (1) Open grasslands and heathlands without tree colonization; (2) Grasslands in the process of being colonized (scattered pines); (3) Dense and young Scots pine stands; (4) Submature Scots pine stands with recent beech installation; (5) Mature Scots pine stands with old beech individuals; (6) Mature and pure beech forest.

\begin{tabular}{lcccccc}
\hline Stages & 1 & 2 & 3 & 4 & 5 & 6 \\
\hline 1 & - & 0.78 & 0.76 & 0.58 & 0.50 & 0.28 \\
2 & - & - & 0.88 & 0.87 & 0.52 & 0.30 \\
3 & - & - & - & 0.64 & 0.55 & 0.32 \\
4 & - & - & - & - & 0.74 & 0.37 \\
5 & - & - & - & - & - & 0.44 \\
6 & - & - & - & - & - & - \\
\hline
\end{tabular}

important, especially when involving the ejection of propagules out of capsules in non-colonized heathlands (data not shown). Conversely, wind dispersal was maximal in early- and late-successional woody stages. Barochory is only important in mature beech stands.
The grazing value (Tab. III) is maximal in the early stages of colonization, although young pine stands exhibit a high amount of toxic and thorny species such as Juniperus communis and Ranunculus nemorosus. During the second step, the grazing value clearly decreased with beech establishment and stand maturation. Plant adaptive strategy varies with forest colonization (Tabl. III). CSR-strategists are predominant, except during early colonization by pine. Stress-competitive species (SC) clearly increase with the stand maturation gradient while stress-tolerators (S) decrease (e.g. Nardus stricta). Competitive-strategists (C) increase with tree colonization and canopy closure, whereas ruderals $(\mathrm{R})$ and stress-ruderals (SR) decrease. Early colonization by pine is likely to differ from the other stages, since it exhibits maximal values for $S$, $\mathrm{SC}, \mathrm{SR}$ and $\mathrm{R}$ species and a clear drop for C, CR and CSR species.

\subsection{Ellenberg values vs. stand evolution}

The Ellenberg score for light decreases continuously throughout forest colonization and maturation (Fig. 5). The scores for nitrogen and humidity show a marked contrast between the earlier stages (heathlands and pure pine stands) and the maturest stands (mixed stands and beech stands). They 

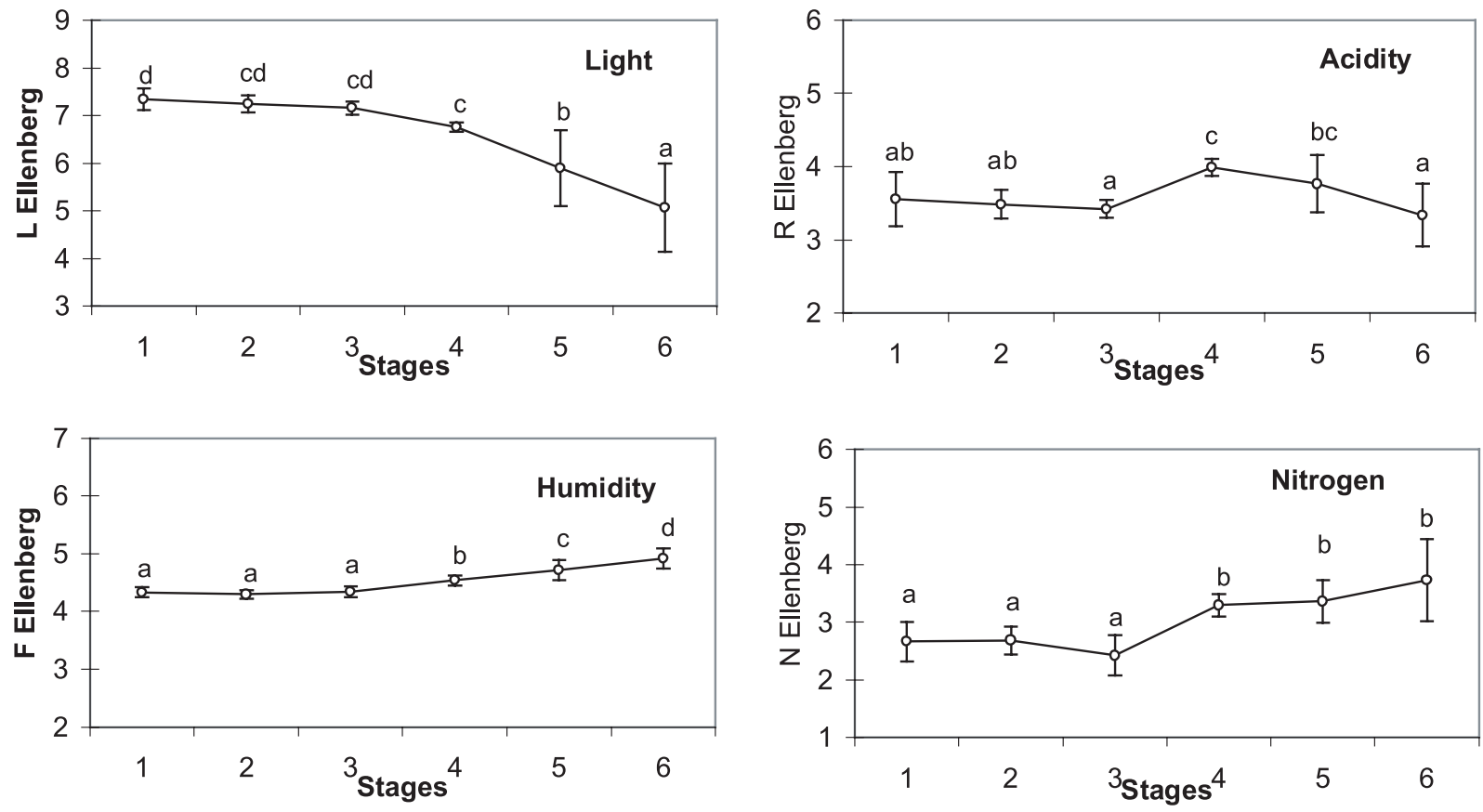

Figure 5. Ellenberg scores for light, humidity, nitrogen and acidity according to the six main stages. The central lozenge is the mean value, and vertical bars are standard errors. Physiognomic stages: (1) Open grasslands and heathlands without tree colonization; (2) Grasslands in the process of being colonized (scattered pines); (3) Dense and young Scots pine stands; (4) Submature Scots pine stands with recent beech installation; (5) Mature Scots pine stands with old beech individuals; (6) Mature and pure beech forest.

are fairly constant in the earlier stages, then increase considerably in mature stands. The scores for temperature and continentality show chaotic variations. The acidity score is maximal in mixed stands, otherwise no statistically significant variation is shown. Scores for light, humidity and nitrogen are strongly correlated: humidity and nitrogen correlate positively, and vary conversely to light (Fig. 6).

\section{DISCUSSION}

\subsection{Stand dynamics}

The colonization process by Scots pine and the subsequent establishment of beech on Mont-Lozère are typical of singlecohort stand dynamics [39] that occur in most pine invasions and post-grazing secondary successions $[1,20,57]$. The traditional agropastoral system including grazing and shrub-clearing was proven to be an effective means of controlling pine invasion $[3,20]$, but grazing cessation allows pine invasion. During the initiation stage, low-density pine stands colonized the open heathlands owing to the pre-existence of local seed sources (i.e. isolated pines and clusters) that were traditionally planted or sowed as shelter for sheep [9]. They are clearly visible in aerial photographs in taken in 1947 and 1955, and in our dendrometric data (specimens of about 65 yrs. in 2001). These pines would have been sexually-mature at the age of about 1520 yrs. [15], i.e. around 1950. This corresponds to the approximate date of the abandonment of sheep grazing estimated by dendrometric data, diachronic analysis of aerial photographs, and oral testimonies from private owners. Thus, the existence of initial foci allowed pine expansion in an environment made favorable by the cessation of grazing.

Secondly, pine stands presumably exhibited an intensive densification stage similar to that visible at present in young and dense pine stands, and in aerial photographs (1955-19631977). Such rapid "infilling" dynamics forming complete cover from initial foci implies synergistic effects: (i) a small area with "aggressive landscape invaders" [47] such as winddispersed species (e.g. pines); (ii) large and close seed sources resulting in a high propagule pressure; (iii) favorable mast years [20]; and (iv) a low resistance of background vegetation at the beginning of pine colonization [9, 16, 27, 44]. Afterwards, dense and close pine woodlands were concerned by a stem exclusion process owing to interspecific competition, which explains the low density of present mature pine stands $[39,42]$. It is noteworthy that young pine stands exhibit a recent re-initiation stage: i.e. a rapid installation of 5 to 10 -yrs. pine saplings in gaps. This could correspond to the recent abandonment of cattle grazing (1990-95) that succeeded traditional sheep grazing, or to the increase of reproductive pines.

In submature stands, the establishment of late-successional beech under the pine canopy corresponds to an "understory reinitiation" stage [39]. Higher beech densities are preferentially located close to old beech thickets and mature beech stands, since this species has a short-distance dispersal by jays and small rodents [38]. The replacement of pine by beech is very rapid: beech seedlings install about 35 to 50 yrs. after the peak pine invasion in most mixed stands. Pine regeneration is 

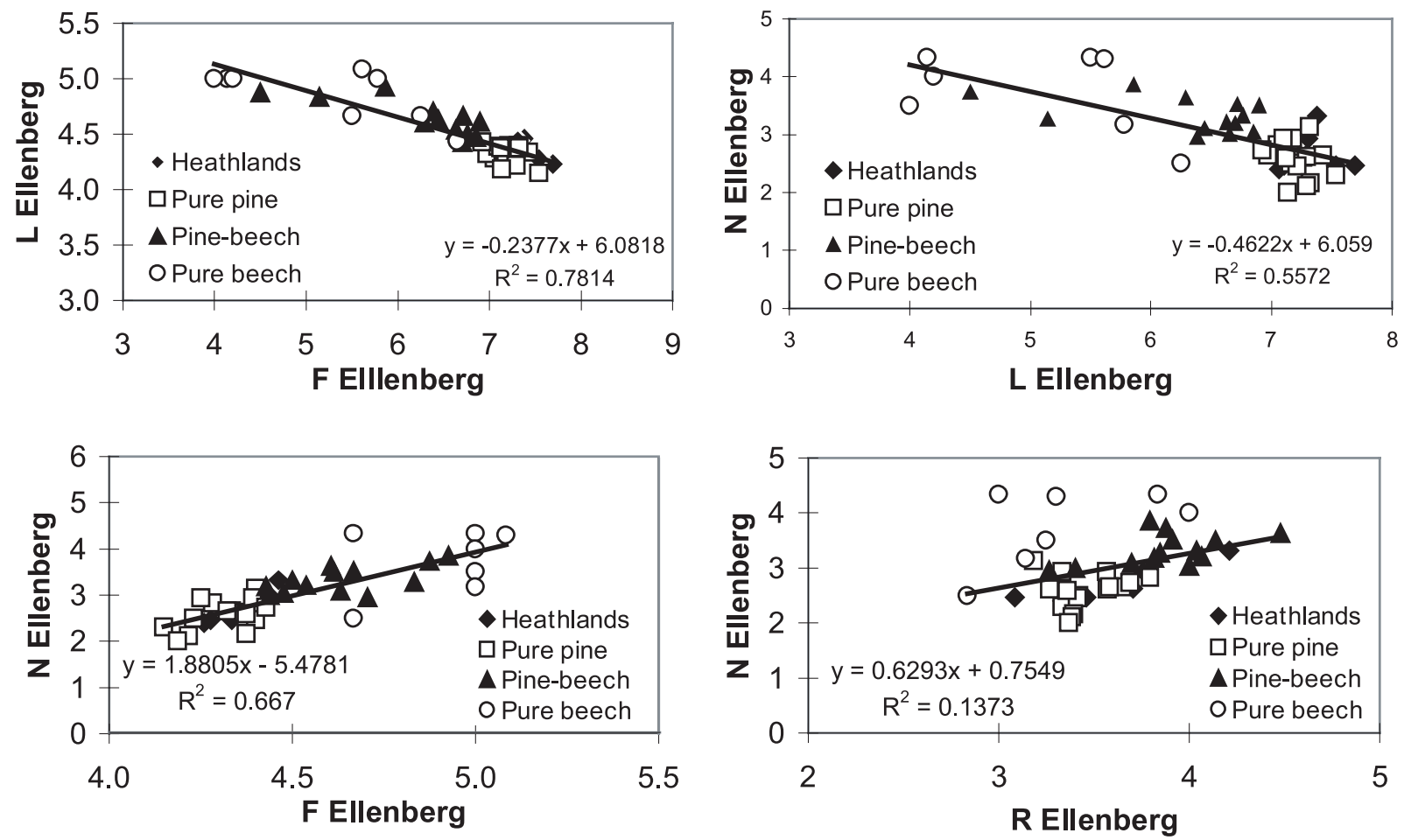

Figure 6. Correlation between the Ellenberg scores for light $(\mathrm{L})$, soil humidity $(\mathrm{F})$, soil acidity $(\mathrm{R})$ and nitrogen $(\mathrm{N})$. Plots were grouped in four categories: open heathlands and grasslands, pure pine stands, mixed (i.e. pine-beech) stands, and pure beech stands.

almost absent in submature and mature stands, most likely in relation to a low light regime [20] and possibly to the depletive effect of the beech humus layer [56], allelopathy and competition with understory vegetation [10].

A limitation of these findings results from using a synchronic approach for studying forest succession. Reconstruction of succession using present stands remains delicate, since biotic and abiotic parameters that play a key role in natural afforestation may have changed [28]: i.e. date and mode of grazing abandonment, number and geometry of seed sources, resistance of ground vegetation to tree establishment, and climatic conditions.

\subsection{Changes in vegetation composition}

Most grassland and heathland species persisted throughout woodland establishment, and some exhibit constant abundance. This finding is in agreement with most studies on postgrazing succession $[48,52,57]$, which indicate that heathland species persist outside their typical habitat, even if they are sometimes sterile [16]. Heathland communities are almost completely preserved in the early stages of colonization by Pinus sylvestris owing to multiple causes. First, short-duration succession tends to limit species turnover since abiotic conditions (e.g. soil quality) are not radically changed [24], as confirmed by the constancy of the Ellenberg scores. Second, young and spatially-heterogeneous pine stands exhibit large gaps that allow shade-intolerant heathland species to persist.
In e.g. strict heathland stress-tolerators are favored in patches of bare soil without accumulation of soil litter [1]. Third, the persistence of heathland endomycorrhizas, and delayed installation of forest exomycorrhizas could also explain the limited changes in vegetation [51]. Fourth, the fragmented landscape favors the installation of heathland species from contiguous sources. However, typical subalpine and Mediterranean heathland species with low dispersal ability disappear in the early stages of pine installation (e.g. Potentilla aurea, Festuca arvernensis or Phyteuma hemisphaericum).

In contrast, submature- and mature mixed stands entail significant changes in vegetation turnover and richness in comparison with initial heathlands. Their richness could result from the persistence of heathland species, and the simultaneous installation of shade-tolerant and mesic forest species in relation to canopy closure and the modification of site quality (e.g. [24]). Improvement of site quality is confirmed by higher soil mineralization and soil moisture regime (i.e. higher Ellenberg $\mathrm{N}$ and $\mathrm{F}$ values).

Mature beech stands correspond to major changes in site conditions and vegetation composition, and to a sharp decrease of species richness. Beech is likely to be a "monopolistic" (sensu Tilman and Pacala [53]) or a "keystone" species (sensu Mills et al. [35]) which strongly affects vegetation communities while it prevents the regeneration of other tree species (i.e. pine). Similar results were found following woody invasion by Pinus [1, 2, 47], Rhododendron ferrugineum [19] or Alnus viridis [2]. 
Most studies on secondary successions have indicated a rapid turnover of species in the initial stages of colonization followed by a slowing down, which generally corresponds to the replacement of ruderals by competitors, stress-tolerant competitors and stress-tolerators [23]. In comparison, Mont-Lozère's heathlands exhibited high inertia, i.e. high persistence of species along forest succession. This could result from a high resistance of ground vegetation to the installation of forest species [5], or from the isolation and fragmentation of forest habitats (e.g. [21]) since typical forest species exhibit low migration rates [6] in relation to low seed production and dispersal rates [25].

\subsection{Interest and limits of richness and diversity indices}

Open heathlands and pure pine woodlands exhibit similar species richness and diversity in spite of some differences existing between vegetation communities. The values are higher than those reported in the French literature on post-grazing succession in grasslands (e.g. $[48,56])$ : the ShannonWeaver diversity index is generally lower than 4 , while the species richness per survey is 20 to 25 . This confirms that the Mont-Lozère heathlands are species-rich and diverse in relation to Mediterranean and mountainous climatic influences [8].

The pattern of species richness along forest succession or woody invasion is a controversial topic since results are often contradictory (review in Levine \& D'Antonio [31]). Our results indicated higher richness in heterogeneous and transitional woodlands, thus agreeing with numerous studies (e.g. [24]) and fitting with the "disturbance hypothesis" [23]. Possible causes for coexistence of forest and heathland species are stand patchiness [1], heterogeneity of site conditions [20], and the absence of a humus layer that eliminates most heathland species [40]. Conversely, the acidic beech forests of MontLozère are comparatively poor in relation to canopy closure and their low light regime. Our results confirm that similarity indices and functional traits are suitable for studying post-disturbance successions [34] since they clearly indicate species turnover, and the extinction of some specific (i.e. endemic) species, whereas the diversity index indicates rather constant richness along succession.

\subsection{Forest colonization, functional changes and succession mechanisms}

Heathlands included a large number of mountainous, subalpine, circumboreal and endemic species belonging to Nardetalia, Nardion and Violion. Some disappear through forest succession to the benefit of cosmopolitan, Mediterranean, forest and indifferent species. These changes can be related to the improvement of microclimatic conditions within woodlands [2]. Most heathland species were wind- or animal-dispersed, and these dispersal processes are logically less efficient after the cessation of grazing [30] and the advent of forest obstruction. Maximal amounts of ligneous endozoochores at intermediate stages may be explained by the development of shrubs and ligneous species supplying perching places, which attract frugivorous birds [48]. Likewise, shrubs take part in the increase of unpalatable species at intermediate stages (e.g. [48]). Our findings on predominant vegetation life forms through successional stages are in accordance with the litera- ture [23, 44]: therophytes, geophytes and chamaephytes decrease with succession while phanerophytes increase.

Our study confirms that Ellenberg's scores for light, humidity and nitrogen are efficient for assessing the impact of forest colonization on former heathlands [17, 49]. The light score especially indicated the replacement of heathland lightdemanding species by shade-tolerant forest species. According to the Ellenberg's scores, mature forest stands benefited from high soil water and nutrient status, and favorable microclimatic conditions. These changes are coherent with the replacement of stress-tolerators, superior colonists and undemanding species (sensu Grime [23]) by poorer colonists but nutrient-demanding and competitive species. This finding is in agreement with the "colonization - nutrient competition" hypothesis proposed by Tilman [53], and with the hypothesis of vegetation stabilization after disturbance [5]. Intermediate stages exhibit high rates of opportunistic CSR-strategists (e.g. r-type demographic strategy), which are progressively replaced by stress-competitor and long-lived species [23]. To conclude, our approach has two major limits: first, the inconsistency of data for Grime's strategy (e.g. missing data) tends to limit the explanation and generalization of such results (see Hermy et al. [25]). Second, determining whether changes in vegetation result from changes in abiotic conditions (humus layer, light regime, soil moisture or mineralization) or the cessation of grazing remains difficult.

\subsection{Implications for management practices and diversity conservation}

Increasing surfaces throughout the world are subject to potential conflicts between the objectives of nature conservation (i.e. maintaining the specific diversity and openness of heathlands) and spontaneous forest dynamics (i.e. colonization/invasion) following the cessation of traditional agricultural practices [36]. In Mont-Lozère, short-term colonization by Scots pine does not entail drastic changes in the plant community, contrasting with pine invasions in the Southern hemisphere [46]. However, some rare and protected heathland species disappear at the early stages of grazing abandonment and forest colonization. Maintaining or restoring high vegetation diversity and endemism in grasslands could be favored by controlled grazing, shrub-clearing, and preservation of diversified landscape patterns permitting connectivity between seed sources [3, 36]. But forest dynamics could also be of interest. Pine and mixed woodlands have a low timber value but they exhibit maximal species richness and diversity, and supply favorable habitats for Black Grouse (Tetrao urogallus). Dynamic silvicultural practices could maintain such natural woodlands as an ecotone between heathlands and beech forest. Likewise, managing spontaneous forest succession towards the restoration of beech forest habitats (e.g. [41]) could also be of interest since they have a high long-term ecological value [8].

Acknowledgements: We are very grateful to Ms. Monique Bouchaud and Céline Marcelot for their valuable help in the field, and to the staff of the Cévennes National Park (Florac) for their support. We also greatly acknowledge the two anonymous reviewers for their help to improve the manuscript, and M. Keith Hodson for correcting the English text. This research was funded by the French Ministry for Environment (Nature and Landscape Department, 2000059 069U). 
Appendix. Abundance of plant species as a function of the natural afforestation gradient. Coefficients after Braun-Blanquet 1935 [7]. Nomenclature follows Flora Europea (Tutin et al. 1980, cf. [54]). Infrequent species (occurrence < 3 in all the relevés) were omitted.

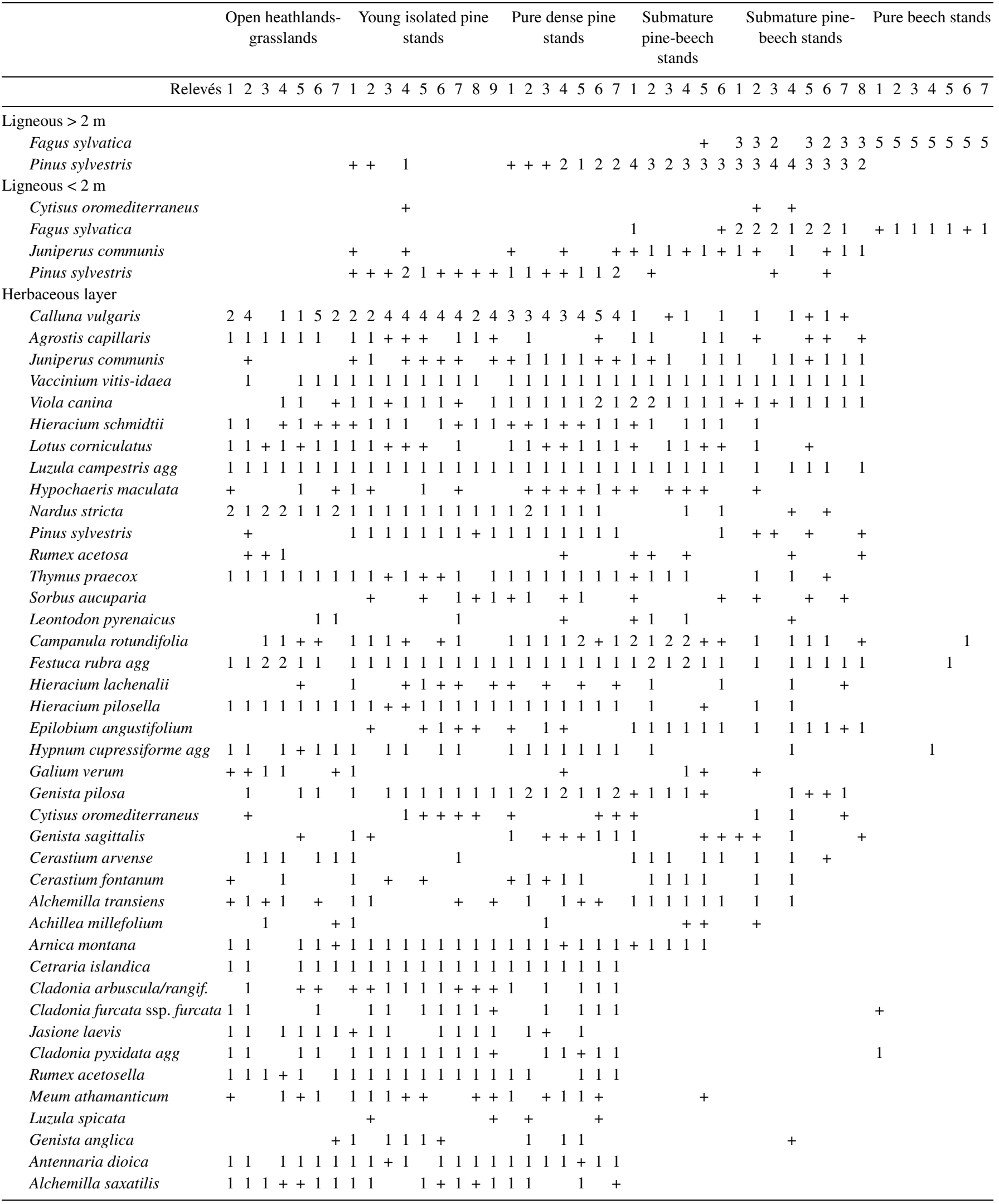


Appendix. Continued.

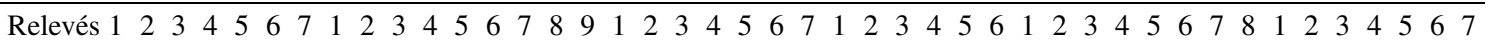

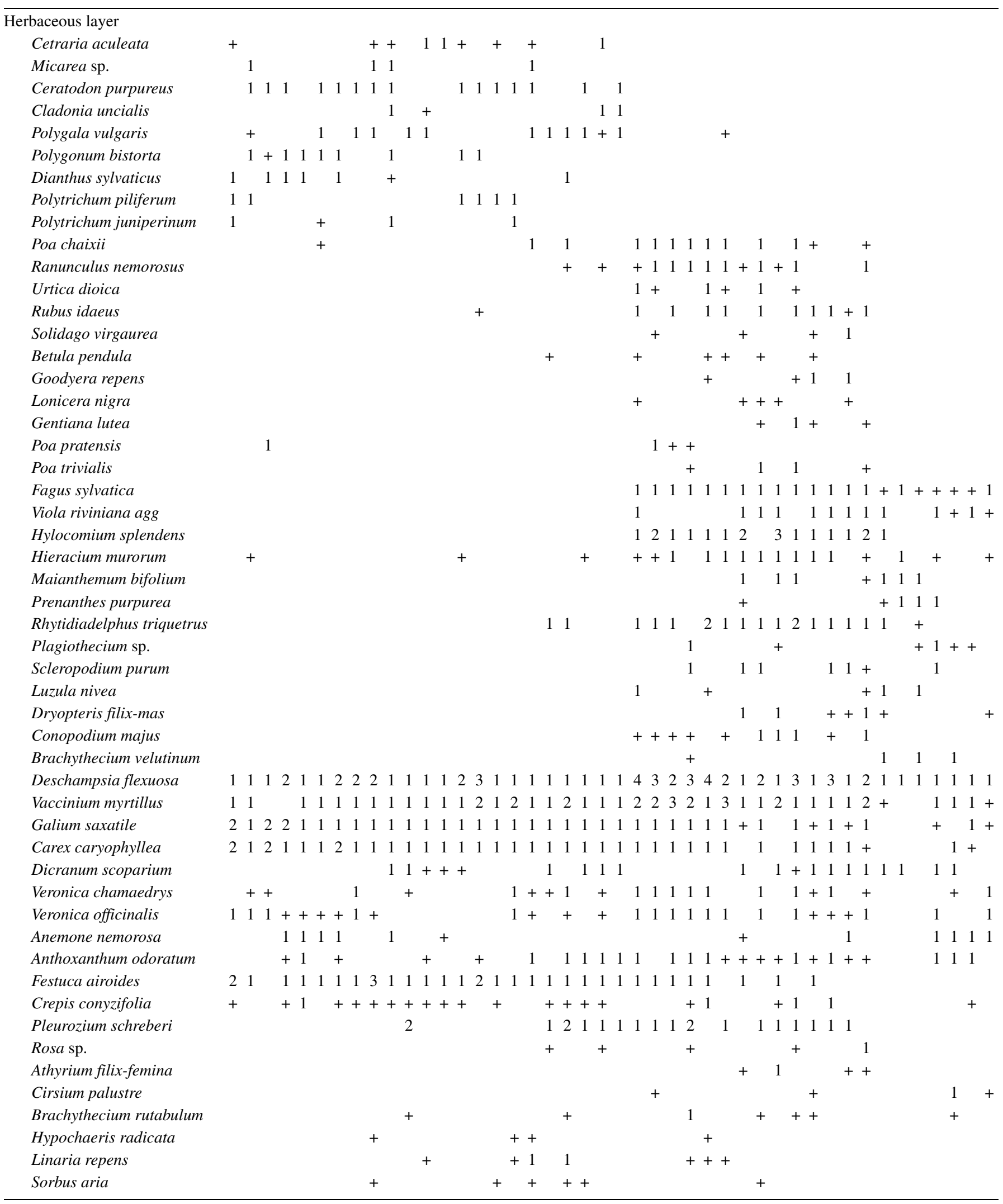




\section{REFERENCES}

[1] Andrés C., Ojeda F., Effects of afforestation with pines on woody plant diversity in Mediterranean heathlands in southern Spain, Biodivers. Conserv. 11 (2002) 1511-1520.

[2] Anthelme F., Grossi J.L., Brun J.J., Didier L., Consequences of green alder expansion on vegetation changes and arthropod communities removal in the northern Alps, For. Ecol. Manage. 145 (2001) 7-65.

[3] Barbaro L., Dutoit T., Cozic P., A six-year experimental restoration of biodiversity by shrub-clearing and grazing in calcareous grasslands of the French Prealps, Biodivers. Conserv. 10 (2001) 119-135.

[4] Barbéro M., Loisel R., Quezel P., Richardson D.M., Romane F., Pines of the Mediterranean Basin, in: Richardson D.M. (Ed.), Ecology and Biogeography of Pinus, Cambridge University Press, Cambridge, 1998, pp. 153-170.

[5] Bazzaz F.A., Plants in changing environment, Linking physiological, population and community ecology, Cambridge Univ. Press, 1998.

[6] Bossuyt B., Hermy M., Deckers J., Migration of herbaceous plant species across ancient-recent forest ecotones in central Belgium, J Ecol. 87 (1999) 628-638.

[7] Braun-Blanquet J., Plant Sociology, The study of Plant Communities. McGraw Hill, New York, Reprint 1983, Koeltz, Koenigstein, 1933.

[8] Braun-Blanquet J., Essai sur la végétation du mont Lozère comparée à celle de l'Aigoual, Bull. Soc. Bot. Fr., 1952, 50 p.

[9] Castro J., Gómez J.M., García D., Zamora R., Hódar J.A., Seed predation and dispersal in relict Scots pine forests in southern Spain, Plant Ecol. 145 (1999) 115-123.

[10] Coll L., Balandier P., Picon-Cochard C., Prévosto B., Curt T., Competition for water between beech seedlings and surrounding vegetation in different light and vegetation composition conditions, Ann. For. Sci. 60 (2003) 593-600.

[11] Coste H., Flore descriptive et illustrée de la France, A. Blanchard (Ed.), 3 vol., 1990.

[12] Cronk Q., Fuller J., Plants invaders: the threat to natural systems, New York, Chapman \& Hall Ed., 1995.

[13] Daget P., Poissonnet J., Prairies permanentes. Méthodes d'étude, Masson, Paris, 1991.

[14] Debain S., Curt T., Lepart J., Seed mass, seed dispersal capacity and seedling performance in a Pinus sylvestris population, Ecoscience 10 (2003) 168-175.

[15] Debain S., Curt T., Lepart J., Prevosto B., Variation of reproduction and seed dispersal in an invasive species: the case of Pinus sylvestris L. expansion in the Causse Méjean, Southern France, J. Veg. Sci. 14 (2003) 509-516.

[16] Debussche M., Debussche G., Lepart J., Changes in the vegetation of Quercus pubescens woodland after cessation of coppicing and grazing, J. Veg. Sci. 12 (2001) 81-92.

[17] Dzwonko Z., Loster S., Effects of dominant trees and anthropogenic disturbances on species richness and floristic composition of secondary communties in southern Poland, J. Appl. Ecol. 34 (1997) 861-870.

[18] Ellenberg H., Weber H.E., Düll R., Wirth V., Werner W., Paulissen D., Zeigerwerte von pflanzen in Mitteleuropa, Scripta Geobot. 18 (1992) 1-248.

[19] Escaravage N., Pornon A., Doche B., Évolution des potentialités dynamiques des landes à Rhododendron ferrugineum L. avec les conditions de milieu, Ecologie 27 (1996) 35-50.

[20] González-Martínez S.C., Bravo F., Density and population structure of the natural regeneration of Scots pine (Pinus sylvestris L.) in the High Ebro Basin (Northern Spain), Ann. For. Sci. 58 (2001) 277-288.

[21] Grashof-Bokdam C.J., Geertsema M., The effect of isolation and history on colonisation patterns of plant species in secondary forests, J. Biogeogr. 25 (1998) 837-846.
[22] Grime J.P., Hodgson J.G., Hunt R., Comparative plant ecology: a functional approach to common British species, Unwin Hyma, London, 1988.

[23] Grime J.P., Plant Strategies, vegetation processes and ecosystem properties (2nd ed.), Wiley, Chichester, 2001.

[24] Harmer R., Peterken G., Kerr G., Poulton P., Vegetation changes during 100 years of development of two secondary woodlands on abandoned arable land, Biol. Conserv. 3101 (2001) 291-304.

[25] Hermy M., Honnay O., Firbank L., Grashof-Bokdam C., Lawesson J.E., An ecological comparison between ancient and other forest plant species in Europe, and the implication for forest conservation, Biol. Conserv. 91 (1999) 9-22.

[26] Higgins S.I., Richardson D.M., Cowling R.M., Trinder-Smith T.H., Predicting the landscape-scale distribution of alien plants and their threat to plant diversity, Conserv. Biol. 13 (1999) 303-313.

[27] Johnstone I.M., Plant invasion windows: a time-based classification of invasion potential, Biol. Rev. 61 (1986) 369-388.

[28] Koerner W., Dupouey J.L., Dambrine E., Benoît M., Influence of the past land use on the vegetation and soils of present day forest in the Vosges mountain, J. Ecol. 85 (1997) 351-358.

[29] Krebs C.J., Ecological methodology, Harper Colins, New-York, 1989.

[30] Lepart J., Escarré J., La succession végétale, mécanismes et modèles : analyse bibliographique, Bull. Ecol. 3 (1983) 133-178.

[31] Levine J.M., D'Antonio C.M., Elton revisited: a review of evidence linking diversity and invasibility, Oikos 87 (1999) 15-26.

[32] Li T.X., Sosa-Ramirez J., Phytoécologie et potentialités agropastorales et forestières du Mont Lozère, Ph.D. Dissert, USTLMontpellier, 1987, $216 \mathrm{p}$.

[33] Lindacher R., Phanart: Datenbank der Gefässpflanzen Mitteleuropas. Veröff. Geobotan. Inst. Zürich, 1995.

[34] McIntyre S., Lavorel S., Tremont R.M., Plant life-history attributes: their relationship to disturbance response in herbaceous vegetation, J. Ecol. 83 (1995) 31-44.

[35] Mills L.S., Soule M.E., Doak D.F., The Keystone-Species Concept in Ecology and Conservation, Bioscience 43 (1993) 219-224.

[36] Muller S., Dutoit T., Alard D., Grévilliot F., Restoration and rehabilitation of species-rich grasslands ecosystems in France: a review, Restor. Ecol. 6 (1998) 94-101.

[37] Myster R.W., Tree invasion and establishment in old fields at Huchestone Memorial Forest, Bot. Rev. 59 (1993) 251-272.

[38] Nielsen B.O., Beech seeds as an ecosystem component, Oikos 29 (1977) 268-274.

[39] Oliver C.D., Larson B.C., Forest stands dynamics, Wiley, NewYork, 1996.

[40] Pausas J.G., Species richness patterns in the understorey of Pyrenean Pinus sylvestris forest, J. Veg. Sci. 5 (1994) 517-524.

[41] Prach K., Pysěk P., Using spontaneous succession for restoration of human-disturbed habitats: Experience from Central Europe, Ecol. Engineering 17 (2001) 55-62.

[42] Prévosto B., Curt T., Gueugnot J., Coquillard P., Modeling Scots pine growth at mountain level on volcanic substrate, For. Ecol. Manage. 131 (2000) 223-237.

[43] Priha O., Smolander A., Nitrogen transformations in soil under Pinus sylvestris, Picea abies and Betula pendula at two forest sites, Soil Biol. Biochem. 31 (1999) 965-977.

[44] Quézel P., Barbéro M., Bonin G., Loisel R., Recent plant invasions in the circum-Mediterranean region, in: DiCastri, Hansen, Debussche (Eds.), Biological invasions in Europe and the Mediterranean basin, Kluwer Acad. Publ., 1990, pp. 51-60.

[45] Raunkiaer C., The life forms of plants and statistical plant geography, Clarendon Press, Oxford, 1934.

[46] Richardson D.M., van Wilgen B.W., Higgins S.I., Trinder-Smith T.H., Cowling R.M., McKelly D.H., Current and future threats to biodiversity on the Cape Peninsula, Biodivers. Conserv. 5 (1996) 607-647.

[47] Richardson D.M., Higgins S.I., Pines as invaders in the southern hemisphere, in: Richardson D.M. (Ed.), Ecology and Biogeography of Pinus, Cambridge Univ. Press, Cambridge, 1998, pp. 450-473. 
[48] Saïd S., Floristic and life form diversity in post-pasture successions on a Mediterranean island (Corsica), Plant Ecol. 162 (2001) 67-76.

[49] Schaffers A.P., Sýkora K.V., Reliability of Ellenberg indicator values for moisture, nitrogen and soil reaction: a comparison with field measurements, J. Veg. Sci. 11 (2000) 225-244.

[50] Shannon C., Weaver W., The mathematical theory of communication, Univ. Illonois Press, Urbana, 1949.

[51] Smith S.E., Read D.J., Mycorrhizal Symbiosis, Academic Press, London, 1997.

[52] Tatoni T., Roche P., Comparison of old-fields and forest revegetation dynamics in Provence, J. Veg. Sci. 5 (1994) 295-302.

[53] Tilman D., Constraints and tradeoffs: toward a predictive theory of competition and succession, Oikos 58 (1990) 3-15.
[54] Tutin T.G., Heywood V.H., Burges N.A., Moore D.M., Valentine D.H., Walters S.M., Webb D.A., Flora Europaea, Cambridge Univ. Press, 1966-1980.

[55] Van der Maarel E., Transformation of cover-abundance values in phytosociology and its effects on community similarity, Vegetatio 39 (1979) 97-144.

[56] Vanpeene-Bruhier S., Moyen M.L., Brun J.J., La richesse spécifique : un outil pour la prise en compte de la biodiversité dans la gestion de l'espace, Ingénieries-EAT 15 (1998) 47-59.

[57] Verdú J.R., Crespo M.B., Galante E., Conservation strategy of a nature reserve in Mediterranean ecosystems: the effects of protection from grazing on biodiversity, Biodivers. Conserv. 9 (2000) 1707-1721. 